\title{
Peripheral blood lymphocyte subsets counts in children on regular hemodialysis
}

\author{
Manal Abd El-Salam ${ }^{1}$, Shaimaa Abdelmalik Pessar ${ }^{2}$ \\ ${ }^{1}$ Department of Pediatrics, Faculty of Medicine (for girls), Al-Azhar University, Cairo, Egypt \\ ${ }^{2}$ Department of Clinical and chemical pathology, Faculty of Medicine Ain Shams University, Cairo, Egypt
}

Email address:

Manal_679@yahoo.com (M. A. El-Salam)

To cite this article:

Manal Abd El-Salam, Shaimaa Abdelmalik Pessar. Peripheral Blood Lymphocyte Subsets Counts in Children on Regular Hemodialysis. International Journal of Immunology. Vol. 3, No. 1, 2015, pp. 1-6. doi: 10.11648/j.iji.20150301.11

\begin{abstract}
Background: Hemodialysis (HD) procedure per se as well as disturbances in both innate and adaptive immunity makes HD patients susceptible to infections. Infections are the major cause of morbidity and the second cause of death following cardiovascular events in HD patients. Aim: Was to study lymphocyte subset counts in children with chronic kidney disease on regular hemodialysis in comparison with normal subjects to clarify the abnormalities in cellular immune profile. Patients and methods: The study included 40children with chronic kidney disease on regular hemodialysis and 20 healthy control (HC) children age and sex matched as a control group, they were selected from the pediatric hemodialysis unit and out patients clinic of AL-zahraa hospital ,AlAzher university during the period from September 2013to June 2014. We examined the number of the peripheral lymphocytes. Also quantification of (T CD3+ \& B CD19+) lymphocytes and T cell subsets including T helper CD3+CD4+, T cytotoxic CD3+ CD8+, CD4/CD8 ratio, and NK cells CD3-CD56+ using flow cytometric analysis and correlates their number with clinical and laboratory characteristics. Results: The total peripheral blood lymphocyte count was lower in HD children $\left(2.3 \mathrm{x} 10^{3} / \mathrm{uL}\right)$ than $\mathrm{HC}$ children $(3$ $\left.\mathrm{x} 10^{3} / \mathrm{uL}\right)$, also T lymphocytes CD3+ counts were reduced in HD children $(1609.25 \pm 545.77 / \mathrm{uL})$ than $\mathrm{HC}(2114.20 \pm 868.39 / \mathrm{uL})$, $(\mathrm{p}=0.008)$, numbers of $\mathrm{CD} 4+\mathrm{T}$ cells were not different, but numbers of $\mathrm{CD} 8+\mathrm{T}$ cells were lower in HD children $(600.67 \pm 284.92)$ compared with HC $(896.80 \pm 573.00)(p<0.05)$. Decrease in NK cell counts CD3-CD56+ in HD children $(175.35 \pm 107.44)$ in comparison to HC (271.30 \pm 169.94$)$. The B lymphocyte count CD19+ was not different in HD children (260 \pm 201.6$)$ compared with healthy controls (250.20 \pm 122.84$)$. A positive correlation was found between B lymphocytes CD19+ with hemodialysis duration. A negative correlation between NK cell counts and BUN, age and also with patients weight and height were found. Conclusion: The reduced numbers of lymphocyte count, $\mathrm{T}$ lymphocytes $\mathrm{CD} 3+$ counts, $\mathrm{CD} 8+\mathrm{T}$ cells as well as NK cell in CKD children on regular hemodialysis may favor the frequent occurrence of infections in spit the normal number of the other studied $t$ cell subsets.
\end{abstract}

Keywords: Hemodialysis, Children, CD4, CD8, CD56, NK Cell

\section{Introduction}

Patients with chronic kidney disease (CKD) have an impairment of the immune response. This is illustrated clinically by an increased incidence of bacterial and viral infections, which are the second most frequent cause of death in these subjects. These patients also have a low rate of response to vaccines, a reduction in delayed hypersensitivity and a high incidence of tumors. Although the exact mechanisms of these immunological alterations in uremia are unknown (Alvarez-Lara et al., 2004) ${ }^{(1)}$.

Hemodialysis (HD) patients are particularly predisposed to infections. It seems that the HD procedure per se as well as disturbances in both innate and adaptive immunity significantly contribute to this susceptibility (Eleftheriadis et al., 2011) ${ }^{(2)}$.

Changes in $\mathrm{T}$ cell subsets and/or function may contribute substantially to the impaired cellular immune response, because ESRD is associated with lymphopenia occurring in the B and T lymphocyte compartment (Kurz et al., 1986; Quadracci et al., 1986; Raska et al., 1983) $)^{(3-5)}$.

Several studies have reported an impaired function of neutrophils, a decrease in the number of lymphocytes, a moderate reduction in $\mathrm{T} \mathrm{CD} 3$ lymphocytes, a decrease in the proportion of CD4 to CD8 and a decrease in the number of $\mathrm{B}$ lymphocytes (Cendroglo et al., 1999; Ferna et al., 2000) ${ }^{(6-7)}$.

The lymphopenia of patients with advanced CKD may be due to a reduction in cell proliferation (Kaul et al., 2000) ${ }^{(8)}$ 
and/or an increase in the rate of T- and B-lymphocyte apoptosis (Ferna et al., 2000) ${ }^{(7)}$. The fact that treatment with haemodialysis reverses some of these abnormalities suggests that uraemia plays a relevant role in the dysfunction of the immune system in CKD patients (Kaul et al., 2000) ${ }^{(8)}$.

The available data on B cell function of patients with ESRD do not indicate an impaired function (Krishnamurthy et al., 2002) ${ }^{(9)}$ The functional data on peripheral $\mathrm{T}$ cells in patients with ESRD are conflicting and obtained by using the unfractionated bulk of circulating T cells (Sester et al., 2000; Libetta et al., 2001) ${ }^{(10-11)}$.

We aimed to study lymphocyte subset counts in children with chronic kidney disease on regular hemodialysis in comparison with normal children to clarify the abnormalities in cellular immune profile.

\section{Patients and Methods}

This is a cross section comparative study; it was carried out in pediatric hemodialysis unit of Al-zahraa hospital, AlAzher University during the period from September 2013to June 2014. The study included 40 children with CKD on regular hemodialysis, for 4 hours/setting, 3 times weekly. They were 20 males and 20 females, their ages ranged from (4-15) years. A group of 20 apparently healthy children with matched age and sex with the patient group, they were 12 males and 8 females. The most common cause of CKD in the patients group was unknown $(44 \%)$ followed by focal segmental glomerulo-sclerosis (20\%). Children with acute and chronic infection or primary immune disorders and on steroids, cytotoxic drugs were excluded from the study, informed consent was obtained from the participating parents in adherence with the guidelines of the ethical committee of AL-Zahraa hospital, AL-Azher university, Cairo, Egypt.

\subsection{Methods}

All studied children were be subjected to:

I- Full medical history taking including:

- Etiology of chronic kidney disease.

- Duration of chronic kidney disease.

- Duration of dialysis.

- History of any other disease.

II- Complete clinical examination

III-Laboratory Investigations
Sample collection:

- $3 \mathrm{ml}$ venous blood samples were withdrawn. The samples were left to clot and sera were separated without delay for the biochemical parameters to be done on the same day including BUN and serum creatinine.

- $3 \mathrm{ml}$ specimens are collected by venipuncture into the K2 EDTA Greiner Germany vacutainer tube for complete blood count (CBC) and T cell subset counts (flow cytometric immunophenotyping).

\subsection{Investigations Including}

BUN, creatinine was done on HITACHII auto analyzer.

Complete blood count (CBC) using [The COULTER ${ }^{\circledR}$ LH 750 Series System (Beckman-Coulter, Miami, Florida)]cell counter five part differential. COULTER ${ }^{\circledR}$ EPICS ${ }^{\circledR}$ XL $^{\text {TM }}$ Flow Cytometer (Beckman-Coulter, Miami, Florida) using flourescin labelled monoclonal Abs:

- T- lineage markers (conjugated anti CD3 Coulter Immunotech).

- Identification of cytotoxic T lymphocytes (conjugated anti CD8, Coulter Immunotech).

- Identification of helper T lymphocytes (conjugated anti CD4, Coulter Immunotech).

- B-lineage markers (conjugated anti CD19 Coulter Immunotech).

- NK- lineage markers (conjugated anti CD56 Coulter Immunotech).

- Fluorochrome-conjugated isotype-matched non-specific $\mathrm{mAbs}$ were used as negative controls for each assay.

\subsection{Statistical Analysis}

The data were revised, coded, and entered to the PC computer and analyzed using SPSS (version 16). Data were expressed descriptively as mean \pm standard deviation (SD) for quantitative parametric data. Comparison between groups was done using the student $\mathrm{t}$ test for parametric data. Spearman correlation: was used to assess the relation between two parameters.

The P-value was considered significant as the following:

- $\mathrm{P}>0.05: \cdot$ Non significant

- $\mathrm{P}<0.05$ : *Significant

- $\mathrm{P}<0.01$ : **Highly statistically significant.

Table (1). Comparison between the two studied groups regarding demographic data, anthropometric measurements and the duration of hemodialysis in the patients group.

\begin{tabular}{|c|c|c|c|c|c|}
\hline \multirow{2}{*}{ Variable } & \multirow{2}{*}{$\begin{array}{l}\text { Control group }(n o=20) \\
\text { Mean } \pm \text { SD }\end{array}$} & \multirow{2}{*}{$\begin{array}{l}\text { Patients group }(\text { no }=40) \\
\text { Mean } \pm \text { SD }\end{array}$} & \multicolumn{3}{|c|}{ Independent t-test } \\
\hline & & & $t / X^{2^{*}}$ & P-value & Sig. \\
\hline Age (years) & $11 \pm 3.464-15$ & $9 \pm 4.33-16$ & $1.781 *$ & 0.080 & NS \\
\hline \multicolumn{6}{|l|}{ Sex $[$ no. $(\%)]$} \\
\hline Female & $12(60.0 \%)$ & $20(50 \%)$ & 0.536 & 0.464 & NS \\
\hline Male & $8(40 \%)$ & $20(50 \%)$ & & & \\
\hline BW (kg) & $32.39 \pm 14.10$ & $22.07 \pm 8.10$ & 3.126 & 0.003 & HS \\
\hline Height (cm) & $132.67 \pm 24.39$ & $107.47 \pm 19.29$ & 3.779 & 0.000 & HS \\
\hline \multirow{2}{*}{ Duration of dialysis (month) } & \multicolumn{2}{|l|}{ Range } & \multicolumn{3}{|l|}{ mean \pm SD } \\
\hline & $3-35$ & & \multicolumn{2}{|l|}{$16.27 \pm 10.02$} & \\
\hline
\end{tabular}

$\mathrm{X}^{2^{*}}$ : Chi-square test 


\section{Results}

Table 1 shows demographic data, anthropometric measurements in the studied groups and the duration of hemodialysis in patients group, it shows a significant decrease in patients weight, height and BMI than in controls and the mean duration of hemodialysis in patients was (16.27) months.

Table (2). Comparison between patients group and the controls regarding laboratory data.

\begin{tabular}{|c|c|c|c|c|c|c|}
\hline \multirow{2}{*}{ Variable } & \multicolumn{2}{|c|}{ Control group $($ no $=20)$} & \multicolumn{2}{|c|}{ Patients group $($ no $=40)$} & \multicolumn{2}{|c|}{ Independent t-test } \\
\hline & Mean & SD & Mean & SD & $t / z^{*}$ & P-value \\
\hline $\mathrm{WBCs}(\mathrm{mm} 3)$ & 7.84 & 2.50 & 6.44 & 2.20 & 2.217 & 0.031 \\
\hline RBCs(millions/mm3) & 4.85 & 0.20 & 3.57 & 0.73 & 6.630 & 0.000 \\
\hline $\mathrm{Hb}(\mathrm{gm} / \mathrm{dL})$ & 13.18 & 0.28 & 9.95 & 1.93 & 6.403 & 0.000 \\
\hline Plat. ( mm3) & 287.20 & 73.28 & 183.47 & 62.02 & 4.978 & 0.000 \\
\hline Creatinine $\mathrm{mg} / \mathrm{dl}$ & 0.35 & 0.13 & 7.42 & 2.61 & -10.423 & 0.000 \\
\hline
\end{tabular}

Table 2 the comparison between patients group and the controls regarding laboratory data: it revealed a significant decrease in (WBCs, RBCS and platelets) counts as well as a significant decrease in $\mathrm{Hb}$ concentration in the patients group than in controls. The same table shows a significant increase in the BUN and serum creatinine levels in patients group than in controls.

Table (3). Comparison between the two studied groups regarding absolute lymphocytic count, T lymphocytes $C D 3+, T$ helper $C D 3+C D 4+, T$ cytotoxic CD3+ CD8+, CD4/CD8 ratio, NK cells CD3-CD56+ and B lymphocytes CD19+.

\begin{tabular}{lllllll}
\hline \multirow{2}{*}{ Variable } & \multicolumn{2}{l}{ Control group $(\mathbf{n o}=\mathbf{2 0})$} & \multicolumn{2}{l}{ Patients group $(\mathbf{n o}=\mathbf{4 0})$} & \multicolumn{2}{l}{ Independent t-test } \\
\cline { 2 - 7 } & Mean & SD & Mean & SD & t/z & P-value \\
\hline Absolute lymphocytic count $\left(\mathrm{x} 10^{3} / \mathrm{uL}\right)$ & 3.00 & 1.14 & 2.33 & 0.76 & 2.682 & 0.010 \\
T lymphocytes CD3+ $(/ \mathrm{uL})$ & 2114.20 & 868.39 & 1609.25 & 545.77 & 2.757 & 0.008 \\
T helper CD3+CD4+ & 1025.70 & 425.56 & 911.45 & 322.78 & 1.160 & 0.251 \\
T cytotoxic CD3+ CD8+ & 896.80 & 573.00 & 600.67 & 284.92 & 2.329 & 0.025 \\
CD4/CD8 ratio & 1.71 & 0.37 & 2.04 & 1.28 & $-0.971^{*}$ & 0.337 \\
NK cells CD3-CD56+ & 271.30 & 169.94 & 175.35 & 107.44 & 2.670 & 0.010 \\
B lymphocytes CD19+ & 250.20 & 122.84 & 260.47 & 201.67 & -0.181 & 0.858 \\
\hline
\end{tabular}

$\mathrm{Z}^{*}$ : Mann-Whitney test

Table 3 the comparison between the hemodialysis children and the controls regarding the absolute lymphocytic count, $T$ lymphocytes $\mathrm{CD} 3+$, $\mathrm{T}$ helper CD3+CD4+, T cytotoxic CD3+ CD8+, CD4/CD8, NK cells CD3-CD56+ and B lymphocytes $\mathrm{CD} 19+$; it revealed a highly significant decrease in absolute lymphocytic count, T lymphocytes CD3+, T cytotoxic CD3+ CD8+ and NK cells CD3-CD56+ in the patients group (hemodialysis children) than in healthy controls. While no significant differences were found regarding $\mathrm{T}$ helper CD3+CD4+ and B lymphocytes CD19+.

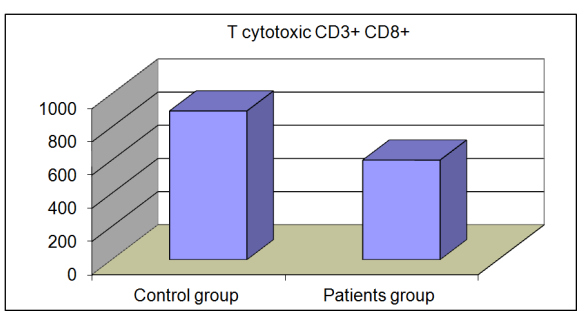

Figure (1). T cytotoxic CD3+CD8+ peripheral counts in hemodialysis children and the controls.

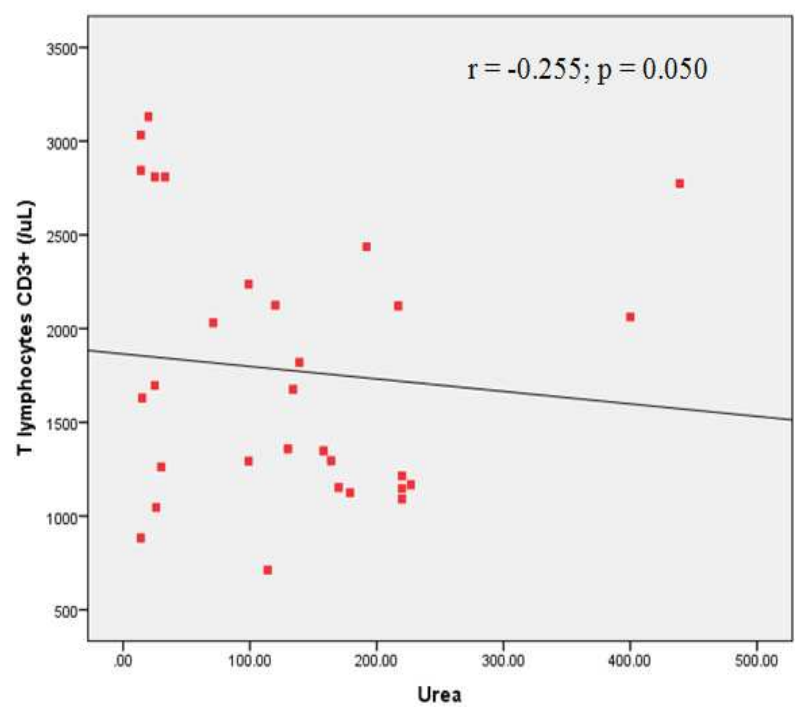

Figure (2). Correlation between Tcell CD3 and BUN. 


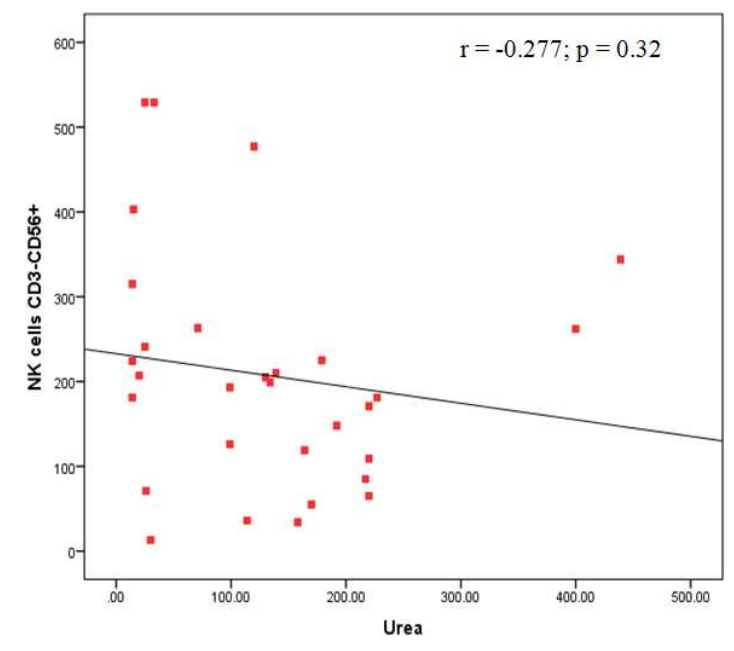

Figure (3). Correlation between $N K$ cell and BUN.

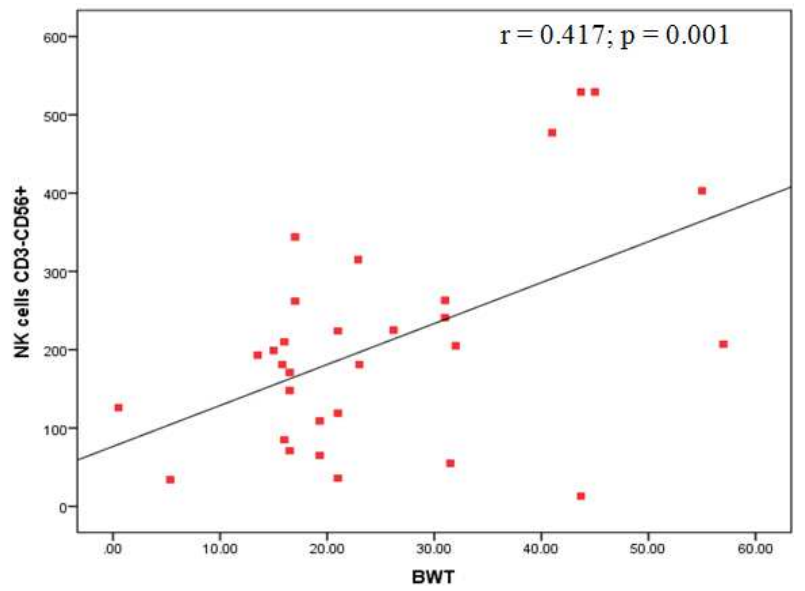

Figure (4). Correlation between NK cell and body weight.

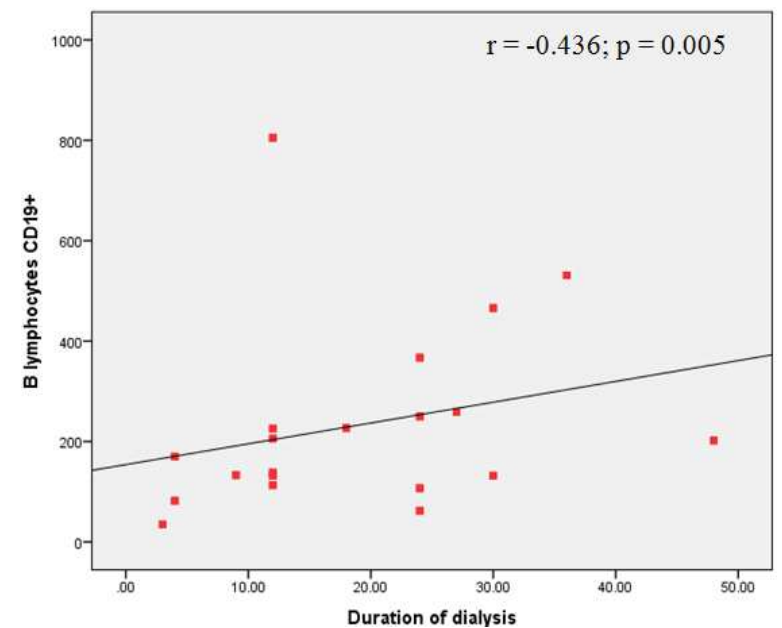

Figure (5). Correlation between B lymphocytes CD19 and duration of hemodialysis.

\section{Discussion}

Patients with chronic kidney disease have been reported to present with immune system changes, such as lower percentages of B and T cells (Chung et al., 2012; Van Pottelbergh et al., 2011) ${ }^{(13-14)}$. A significant number of studies have shown that the decline in kidney function is associated with changes in the immune system. However, these studies are controversial, probably because of the different parameters used to measure kidney function and immune response (Vaziri et al., 2012) ${ }^{(15)}$ and some studies performed in vitro show that T-cell proliferation is decreased in the uremic milieu (Meuer et al.,1987; Stachowski et al., $1993)^{(16,17)}$. However there is a limited data on the lymphocyte subsets counts in children undergoing hemodialysis.

Our concern in the present study is to assess, the peripheral lymphocyte counts (T, B) cells and T cell subsets in children with chronic kidney disease on regular hemodialysis as and to be compared with healthy controls and correlated with the studied clinical and laboratory parameters.

In the present study we confirm reduced number of peripheral blood lymphocytes counts as well as T lymphocytes CD3+ in children with chronic kidney disease on regular hemodialysis than in healthy controls. Reduced lymphocyte counts were identified as predictors of mortality in haemodialysis patients (HD) (Reddan et al., 2003) ${ }^{(18)}$. The reduced number of lymphocyte counts in patients with advanced CKD may be due to a reduction in cell proliferation (Kaul et al., 2000) $)^{(3)}$ and or an increase in cell apoptosis (Fernandez-Fresnedo et al., 2000) ${ }^{(19)}$.

In the present study CD4+ cell counts levels have been shown to be normal in hemodialysis children when compared to healthy controls, while CD8+ T counts were lower in hemodialysis children than healthy controls, consequently there is a difference in $\mathrm{CD} 4 / \mathrm{CD} 8$ ratio but not reached to be of statistical significant difference, this may be attributed to the small sample size and it is one of the study limitation.

T-helper cells, CD4 are necessary for the cell-mediated immune response and for $\mathrm{B}$ cells to differentiate into antibody-producing cells. Cytotoxic $\mathrm{T} \mathrm{CD} 8+\mathrm{T}$ cells are important in the host defense against viral infections (Descamps-Latscha, 1996; Chatenoud, 1990; Furth, 1995; Kawano, 1994) ${ }^{(20-23)}$. Our results might imply that children with chronic kidney disease on regular hemodialysis are more susceptible to such infections also Yoon et al., 2006; Yaghoubian et al., 2011 ${ }^{(24-25)}$ reported ,CD8+ T cell levels have been shown to be decreased in patients with chronic kidney disease. Most studies report a normal ratio of T-helper (CD4) and T-suppressor (CD8) cells (Lewis et al., 1993, Cohen et al., 1997; Van Pottelbergh et al., 2011) ${ }^{(26-27,14)}$. Some studies showed a decreased ratio (Bender et al. 1984; Morra etal., 1990) ${ }^{(28-29)}$

Compared with healthy controls, a decrease in the NK cells CD3-CD56+ counts has been observed in hemodialysis with significant negative correlation was observed with age, weight and height. It remains unclear which factors, hemodialysis per se or uremic toxins, affect NK cell counts. In our study, dialysis duration was not correlated with NK cell counts in contrast to B lymphocytes subsets CD19+ this is in the same line with Vacher-Coponat et al. (2008) ${ }^{30}$ who reported lower NK cell counts in a large group of HD patients and dialysis duration was not correlated with NK cell counts. Also in the same line, the statement of Bender et al. $(1984)^{(28)}$, in chronic 
hemodialysis the NK cells are depressed and the function was not improved with chronic hemodialysis (Kai and Raij, 1986) ${ }^{(31)}$.

Our study report a significant influence of age, weight and height on NK cell counts in HD as a significant part of immune alterations in the course of ESRD which could be probably attributed to the presence of protein energy wasting (PEW) (Fouque et al., 2008) ${ }^{(32)}$. Lowered NK counts were significantly associated with BUN this suggests that uremia plays a relevant role in the dysfunction of the immune system in CKD patients on regular hemodialysis.

Natural killer cells are important in the immune response to viral infections and possibly to malignancies (Lotzova et al., 1993) ${ }^{(33)}$. Furthermore, NK cells can kill antibody-coated bacteria.

Our study demonstrated no significant difference between hemodialysis children and the controls regarding B lymphocytes subsets $(\mathrm{CD} 19+)$ with, $(\mathrm{p}=0.8)$. B cells responsible for antibody production, are generated and maturated in bone marrow mostly by the action of IL-7 (Milne and Paige, 2006; Kalled 2006) ${ }^{(34-35)}$ A decrease in B cells has been shown in children (Bouts et al., 2004) ${ }^{(36)}$ and adults (Pahl et al., 2010) ${ }^{(37)}$ with chronic kidney disease and could be the reason for the defective humoral (antigen specific antibody production) response to infections, vaccinations and recall antigens in these patients. In the present work we found a negative correlation between B CD19+ cells with age and serum creatinine level. It is not surprising to find a positive correlation between B CD19+ cells with the duration of hemodialysis, the fact that treatment with haemodialysis reverses some of these abnormalities suggests that uremia plays a relevant role in the dysfunction of the immune system in CKD patients (Kaul et al., 2000) ${ }^{(38)}$. Inspite, we cannot conclude that the normal peripheral B CD19+ indicates normal B cell function. (Coles et al., 1994; Lewis et al., 1992. Degiannis, 1987) ${ }^{(39-41)}$ reported the B-cell count was lower in $\mathrm{PD}, \mathrm{HD}$, and CRF children, but no significant differences were found in the prevalence of B-cell deficiencies among all the groups.

In conclusion: cellular immunity represented in total lymphocytic count, cytotoxic T cells, NK cells are reduced in number in children with chronic kidney disease on regular hemodialysis which explain the frequent occurrence of infection particularly viral infections and malignancies in this group, thus, we recommend further studies with functional assays to assess immune cell functions rather than frequency.

\section{References}

[1] Alvarez-Lara MA, Carracedo J, Rafael RR, Alejandro MM, Mariano R, Juan AM and Pedro A .The imbalance in the ratio of Th1 and Th2 helper lymphocytes in uraemia is mediated by an increased apoptosis of Th1 subset1 Nephrol Dial Transplant 2004; 19: 3084-3090.

[2] Eleftheriadis T, Liakopoulos V, Leivaditis K, Antoniadi G, Stefanidis I. Infections in hemodialysis: a concise review. Part II: blood transmitted viral infections. Hippokratia 2011; 15(2): 120-126.
[3] Kurz P, Kohler H, Meuer S, Hutteroth T, Meyer zum Buschenfelde $\mathrm{KH}$. Impaired cellular immune responses in chronic renal failure: Evidence for a $\mathrm{T}$ cell defect. Kidney Int 1986; 29: 1209-1214.

[4] 4 Quadracci LJ, Ringden O, Krzymanski M . The effect of uremia and transplantation on lymphocyte subpopulations. Kidney Int1976; 10: 179-184.

[5] Raska K Jr, Raskova J, Shea SM, Frankel RM, Wood RH, Lifter J, Ghobrial I, Eisinger RP, Homer L . T cell subsets and cellular immunity in end-stage renal disease. Am J Med 1983;75: 734-740.

[6] 6 Cendroglo M, Jaber BL, Balakrishnan VS, Perianayagam M, King AJ, Pereira BJ. Neutrophil apoptosis and dysfunction in uremia. J Am Soc Nephrol 1999 ;10: 93-100.

[7] Ferna ndez-Fresnedo G, Ramos MA, Gonzalez-Pardo MC, Marti'n de Francisco AL, Lo' pez-Hoyos M, Arias M (2000): $\mathrm{B}$ lymphopenia in uremia is related to an accelerated in vitro apoptosis and dysregulation of Bcl-2. Nephrol Dial Transplant; 15: 502-510.

[8] Kaul H, Girndt M, Sester U, Sester M, Ko“ hler H . Initiation of hemodialysis treatment leads to improvement of $\mathrm{T}$ cell activation in patients with end-stage renal disease. Am J Kidney Dis 2000; 35: 611-616

[9] Krishnamurthy G, Kher V, Naik S. Low response to HBsAg vaccine in chronic renal failure patients is not due to intrinsic defect of B cells. Scand J Urol Nephrol 2002; 36: 377-382.

[10] Sester U, Sester M, Hauk M, Kaul H, Kohler H, Girndt M . Tcell activation follows Th1 rather than Th2 pattern in haemodialysis patients. Nephrol Dial Transplant 2000; 15: $1217-1223$.

[11] Libetta C, Rampino T, Dal Canton A . Polarization of T-helper lymphocytes toward the Th2 phenotype in uremic patients. Am J Kidney Dis 2001; 38: 286-295.

[12] Wilson $\mathrm{K}$ and Walker J. Principle and technology of biochemistry and molecular biology 2005; Six edition.

[13] Chung BH, Kim KW, Sun IO, Choi SR, Park HS, Jeon EJ, et al. Increased interleukin-17 producing effector memory $\mathrm{T}$ cells in the end-stage renal disease patients. Immunol Lett $2012 ; 141(2): 181-9$.

[14] Van Pottelbergh G, Bartholomeeeusen S, Buntix F, Degryse J. The evolution of renal function and the incidence of end-stage renal disease in patients aged $\$ 50$ years. Nephrol Dial Transplant 2011; 27(6):2297-303.

[15] Vaziri ND, Pahl MV, Crum A, Noris K. Effect of uremia on structure and function of immune system. J Ren Nutr 2012; 22(1):149-56.

[16] Meuer SC, Hauer M, Kurz P et al. Selective blockade of the antigen-receptor-mediated pathway of T-cell activation in patients with impaired primary immune responses. J Clin Invest 1957; 80:743-749.

[17] Stachowski J, Pollok M, Burrichter H et al. Signaling via the TCR/CD3 antigen receptor complex in uremia is limited by the receptors number. Nephron 1993; 64:369-375.

[18] Reddan DN, Klassen PS, Szczech LA et al. White blood cells as a novel mortality predictor in haemodialysis patients. Nephrol Dial Transplant 2003 ; 18: 1167-1173 
[19] Fernandez-Fresnedo G, Ramos MA, Gonzalez-Pardo MC, Martı'n de Francisco AL, Lo' pez-Hoyos M, Arias M. B lymphopenia in uremia is related to an accelerated in vitro apoptosis and dysregulation of Bcl-2. Nephrol Dial Transplant 2000; 15: 502-510.

[20] Descamps-Latscha B, Chatenoud L .T cells and B cells in chronic renal failure. Semin Nephrol 1996; 16:183-91.

[21] Chatenoud L, Herbelin A, Beaurain G, Descamps-Latscha B .Immune deficiency of the uremic patient. Adv Nephrol Necker Hosp1990; 19:259-74.

[22] Furth SL, Neu AM, McColley SA, Case B, Steinhoff M, Fivush B. Immune response to influenza vaccination in children with renal disease. Pediatr Nephrol 1995; 9:566-8.

[23] Kawano Y, Noma T, Yata J. Regulation of human IgG subclass production by cytokines. IFN-gamma and IL- 6 act antagonistically in the induction of human IgG1 but additively in the induction of IgG2. J Immunol 1994; 53:4948-58.

[24] Yoon JW, Gollapudi S, Pahl MV, Vaziri ND. Navve and central memory T-cell lymphopenia in end-stage renal disease. Kidney Int 2006; 70(2):371-6.

[25] Yaghoubian A, Ge P, Tolan A, Saltmarsh G, Kaji AH, Neville $\mathrm{AL}$, et al. . Renal insufficiency predicts mortality in geriatric patients undergoing emergent general surgery. Am Surg 2011; 767(10):1322-5.

[26] Lewis SL, Bonner PN, Cooper CL, Holmes CJ. Prospective comparison of blood and peritoneal lymphocytes from continuous ambulatory peritoneal dialysis patients. J Clin Lab Immunol1992; 37:3-19.

[27] Cohen G, Haag-Weber M, Horl WH. Immune dysfunction in uremia. Kidney Int 1997; 52(62):79-82.

[28] Bender BS, Curtis JL, Naegel JE, Chrest FJ, et al. Analysis of the immune status of hemodialyzed adults: Association with prior transfusion .Kidney Int 1984; 26:436-443.

[29] Morra L, Ponassi GA, Gurreri G, Moccia F, Mela GS, Bessone G. T lymphocyte subsets in chronic uremic patients treated with maintenance hemodialysis. Biomed Pharmacother1990; 44:53-6.

[30] Vacher-Coponat H, Brunet C, Lyonnet L, Bonnet E, Loundou A, Sampol J, et al. Natural killer cell alterations correlate with loss of renal function and dialysis duration in uraemic patients. Nephrol Dial Transplant 2008; 23(4):1406-14.

[31] Kay NE and Raij L. Immune abnormalities in renal failure and hemodialysis. Blood purification 1986; 4:120-129.

[32] Fouque D, Kalantar-Zadeh K, Kopple J, Cano N, Chauveau P, Cuppari L, Franch H, Guarnieri G, Ikizler TA, Kaysen G, Lindholm B, Massy Z, Mitch W, Pineda E, Stenvinkel P, Trevinho-Becerra A, Wanner C . A prop osed nomenclature and diagnostic criteria for protein-energy wasting in acute and chronic kidney disease. Kidney Int 2008; 73: 391-398.

[33] Lotzova E. Definition and functions of natural killer cells. Nat Immun1993; 12:169-76.

[34] Milne CD, Paige CJ. IL-7: a key regulator of B lymphopoiesis. Semin Immunol 2006; 18(1):20-30.

[35] Kalled L. Impact of the BAFF/BR3 axis on B cell survival, germinal center maintenance and antibody production. Semin Immunol 2006; 18(5):290-6.

[36] Bouts A, Davin J, Krediet R. Children with chronic renal failure have reduced numbers of memory B cells. Clin Exp Immunol 2004; 137(3):589-94.

[37] Pahl MV, Gollapudi S, Sepassi L, Gollapudi P, Elahimehr R, Vaziri ND . Effect of end-stage renal disease on B-lymphocyte subpopulations, IL-7, BAFF and BAFF receptor expression. Nephrol Dial Transplant 2010; 25(1):205-12.

[38] Kaul H, Girndt M, Sester U, Sester M, Kohler H. Initiation of hemodialysis treatment leads to improvement of $\mathrm{T}$ cell activation in patients with end-stage renal disease. Am J Kidney Dis2000; 35: 611-616

[39] Coles GA, Lewis SL, Williams JD. Host defence and effects of solutions on peritoneal cells. In: Gokal R, Nolph KD, eds. The textbook of peritoneal dialysis. $1^{\text {st }}$ ed. Dordrecht: Kluwer Academic Publishers1994; 503-28.

[40] Lewis SL, Kutvirt SG, Cooper CL, Bonner PN, Holmes CJ. Characteristics of peripheral and peritoneal lymphocytes from continuous ambulatory peritoneal dialysis patients. Perit Dial Int1993; 13(2):273-7.

[41] Degiannis D, Mowat AM, Galloway E, Tsakiris D, Briggs JD, Junor BJ, et al . In vitro analysis of B lymphocyte function in uraemia. Clin Exp Immunol 1987; 70:463-70 